\title{
Direct Effect of $17 \beta$-Estradiol on Striatum: Sex Differences in Dopamine Release
}

\author{
JILL B. BECKER \\ Psychology Department and Neuroscience Program, The University of Michigan, Ann Arbor, Michigan 48104
}

\begin{abstract}
KEY WORDS Estradiol, Dopamine, Striatum, Sex Differences
ABSTRACT The nigrostriatal dopamine (DA) system is sexually dimorphic. In female but not male rats, striatal DA activity is modulated by gonadal steroid hormones. Ovariectomy (OVX) decreases striatal DA release and turnover. Estrogen replacement restores the response to that of the intact female in estrus. In contrast, castration (CAST) of male rats has no effect on the stimulated release of DA from striatal tissue. This report addresses the question: Does estrogen act directly on the striatum to induce changes in DA release? Physiological concentrations of $17 \beta$-estradiol and other steroids or a nonsteroidal estrogen analog were applied directly to striatal tissue maintained in an in vitro superfusion system. The effect of hormonal treatments on the responsiveness of striatal DA terminals to stimulation was examined in tissue from OVX females and intact and CAST male rats. The results are summarized as follows: (1) Infusion of $17 \beta$-estradiol $(\mathrm{p}<0.01)$ and diethylstilbesterol $(\mathrm{p}<0.05)$ increased amphetamine (AMPH)-stimulated striatal DA release from striatal tissue of OVX female rats compared with the effect of cholesterol. 17alpha-Estradiol also tended to potentiate the striatal DA response to AMPH, but this result was not statistically significant $(p<0.062) .17 \beta$-Estradiol had no effect on AMPH-stimulated DA release from striatal tissue of intact male rats. (2) The $\mathrm{KCl}$-stimulated release of DA from striatal tissue of OVX rats exposed in vitro to $100 \mathrm{pg} / \mathrm{ml}$ $17 \beta$-estradiol (a physiological dose) was significantly greater $(p<0.05)$ than the response after exposure to vehicle. In contrast, $1,000 \mathrm{pg} / \mathrm{ml} 17 \beta$-estradiol produced a decrease in $\mathrm{KCl}$-induced striatal DA release ( $\mathrm{p}<0.05)$, whereas 17 alpha-estradiol $(100 \mathrm{pg} / \mathrm{ml}$ or 1,000 $\mathrm{pg} / \mathrm{ml}$ ) did not significantly influence the response to $\mathrm{KCl}$. (3) The pulsatile administration of $17 \beta$-estradiol stimulated DA release from strital tissue of OVX females $(p<0.05$; compared with tissue from an OVX group that received vehicle or CAST male rats exposed to either $17 \beta$-estradiol or vehicle). It is concluded that with tissue from OVX rats, physiological concentrations of estrogen can act directly on striatal tissue in vitro to stimulate DA release and to increase striatal DA responsiveness to stimulation, whereas prolonged exposure or high concentrations of $17 \beta$-estradiol decreases striatal DA responsiveness. The striatum and/or the striatal DA system are sexually dimorphic in this regard.
\end{abstract}

\section{INTRODUCTION}

The nigrostriatal dopamine (DA) system is sexually dimorphic. In female but not male rats, endogenous gonadal hormones modulate striatal DA release and nigrostriatal DA-mediated behaviors (Becker and Ramirez, 1980, 1981; Becker et al., 1982; Robinson et al., 1981, 1982). This sex difference can be seen in the release of DA from striatal tissue fragments in an in vitro superfusion system: amphetamine (AMPH)-stimulated DA release from striatal tissue of female rats is decreased after removal of the ovaries. In contrast, removal of the testes has no effect on the same response in striatal tissue from male rats (Becker and Ramirez, 1980, 1981). This sex difference can also be observed behaviorally. Ovariectomy (OVX) produces a decrease in rotational behavior induced either by electrical stimulation of the nigrostriatal bundle or by AMPH administration, whereas castration of male rats has no effect on either of these behaviors (Camp et al., 1986; Robinson et al., 1981).

In addition to the decrease in striatal DA responsiveness to stimulation that occurs following OVX of female rats, there is estrous cycle dependent variation in striatal DA activity. AMPH-stimulated striatal DA release is greater on estrus than on other days of the estrous cycle. This is true both for DA release studied using an in vitro superfusion system (Becker and Cha, 1989; Becker and Ramirez, 1980) and for DA release from striatum in vivo during microdialysis in freely moving rats (Becker and Cha, 1989). There is also estrous cycle-dependent variation in the density and affinity of

Received August 18, 1989; accepted October 18, 1989.

Address reprint requests to Dr. Jill B. Becker, The University of Michigan, Neuroscience Laboratory Building, 1103 E. Huron St., Ann Arbor, MI 48104-1687. 
striatal DA receptors (Di Paolo et al., 1988; Levesque et al., 1989). Behavioral correlates of these neurochemical changes include estrous cycle-dependent variation in the intensity of AMPH-stimulated stereotyped behaviors (Becker and Cha, 1989), in postural deviation induced by unilateral application of DA into the striatum (Joyce and Van Hartesveldt, 1984a), and in rotational behavior induced either by AMPH (Becker et al., 1982) or electrical stimulation of the nigrostriatal DA bundle (Robinson et al., 1982).

Estrogen is the hormone implicated in these estrous cycle dependent effects, since prior treatment of OVX female rats with physiological doses of estradiol potentiates AMPH-stimulated striatal DA release (Becker and Beer, 1986), increases the rate of striatal DA turnover (Di Paolo et al., 1985), and decreases the number of DA receptors in striatum (Levesque and Di Paolo, 1988). Estrogen may also influence neural activity in the striatum of male rats. Treatment of intact male rats with estrogen produces an increase in rotational behavior and an increase in the number of striatal DA receptors (Hruska, 1986; Hruska et al., 1980; Hruska and Pitman, 1982; Hruska and Silbergeld, 1980).

The mechanism(s) through which estrogen induces these effects on striatal DA activity remains controversial. Recent work has suggested that estrogen may act directly on the striatum in female rats to induce changes in striatal DA activity and DA mediated behaviors. For example, application to the striatum of $17 \beta$-estradiol, but not 17alpha-estradiol, induces an improvement in sensorimotor function in OVX rats (Becker et al., 1987). In addition, following the unilateral application of estradiol to the striatum, apomorphine induces postural deviation and lateralized stereotypic behaviors (Joyce and Van Hartesveldt, 1984b). Therefore, it is hypothesized that estrogen can act directly on the striatum to modulate dopaminergic activity. The results of the present study confirm this hypothesis. It is reported that estradiol acts directly on striatal tissue in vitro to modulate DA release and that there are sex differences in this effect of estradiol.

\section{METHODS \\ Subjects}

Adult male and female Holtzman rats (Madison, WI) were housed 2-3/cage; lights were maintained on a 14:10 light:dark cycle; food and water were freely available. OVX or castration (CAST) was performed under anesthesia (ether or pentobarbital) at least 2 weeks prior to an experiment. Experiments were initially conducted using striatal tissue from intact male rats for two reasons. First, CAST has had no effect on striatal DA release in this system in previous experiments (Becker and Ramirez, 1980) and second, studies examining the behavioral and neurochemical effects of estrogen on the striatal DA system that have been reported were all carried out on intact males (e.g., Hruska and Silbergeld, 1980). Follow-up experiments were conducted with striatal tissue from CAST males, so that male and female groups would be under the same hormonal conditions prior to manipulations in vitro.

On the day of an experiment, animals were decapitated and the brains were rapidly removed. The striata were dissected, chopped into $1 \mathrm{~mm}^{3}$ pieces, and placed into superfusion chambers containing $200 \mu \mathrm{l}$ of medium (see below) warmed to $34-37^{\circ} \mathrm{C}$. At the conclusion of each superfusion, the tissue was removed from the chamber, weighed, homogenized in $0.05 \mathrm{~N} \mathrm{HClO}_{4}$ with a final concentration of $0.0002 \%$ dihydroxybenzylamine (DHBA) as an internal standard and centrifuged at $3,500 \times \mathrm{g}$ for $45 \mathrm{~min}$. DA concentrations were determined as described below.

\section{The superfusion system}

The superfusion chamber construction and system design are described in detail in Becker et al. (1984). Briefly, a modified Krebs-Ringer phosphate medium with $0.1 \%$ bovine serum albumin and $10 \mathrm{mM}$ d-glucose was oxygenated by bubbling with $95 \% \mathrm{O}_{2} / 5 \% \mathrm{CO}_{2}$ for 15 min, and the $\mathrm{pH}$ was adjusted to 7.4. Medium continually flowed through each charnber at a rate of 100 $\mu \mathrm{l} / \mathrm{min}$. The temperature in the chamber was maintained at $34-37^{\circ} \mathrm{C}$ and the effluent from the chamber was collected on ice in plastic tubes containing $25 \mu \mathrm{l}$ of $0.05 \mathrm{~N} \mathrm{HClO}_{4}$ with DHBA (final concentration .0002\%) as an internal standard (controlling for any variation in volume and loss of DA due to oxidation).

\section{Catecholamine assay}

DA and DOPAC concentrations in the effluent and tissue supernatant were measured by high performance liquid chromatography with electrochemical detection (HPLC-EC) after alumina extraction. BioAnalytical Systems Phase II columns (reverse phase, C-18, $3 \mu \mathrm{m}$ particles) were used to separate the monoamines and their metabolites. The mobile phase consisted of a 0.075 $M$ monochloroacetic acid buffer containing $0.1 \mathrm{mM}$ EDTA, $2 \%$ acetonitrile, and $0.15 \mathrm{mM}$ sodium octyl sulfate (pH 3.35 before acetonitrile added). The electrochemical detectors (BioAnalytical Systems, Lafayette, IN) employed a glassy carbon electrode with a potential of $+0.74 \mathrm{~V}$ against a silver/silver chloride reference electrode. The detector sensitivity was set at $5 \mathrm{nA} / \mathrm{V}$. Standards of known concentrations of DA and DOPAC were prepared in medium, underwent alumina extraction with the superfusion effluent samples, and a 4point standard curve was obtained for each assay. The standard curve for DA and DOPAC was linear from $25-2,000 \mathrm{pg} / 20 \mu \mathrm{l}$. In an average superfusion, the DA concentrations in the effluent were $200-800 \mathrm{pg} / 20 \mu \mathrm{l}$, well within the linear range of our standard curves. Endogenous DA release rates were expressed as $\mathrm{pg} / \mathrm{mg}$ tissue/min.

\section{Effects of estrogens on AMPH-stimulated DA release}

Striatal tissue from OVX female rats was collected on ice in medium containing $60 \mathrm{pg} / \mathrm{ml}$ of one of the following (dissolved in $0.001 \%$ ethylene glycol): 1) cholesterol $(\mathrm{N}=8), 2) 17$ alpha-estradiol $(\mathrm{N}=12), 3) 17 \beta$-estradiol $(\mathrm{N}=14)$, or (4) diethylstilbesterol $(\mathrm{N}=6$; DES) and prepared as described above. Striatal tissue from intact male rats was collect in medium containing either: (1) cholesterol ( $\mathrm{N}=4)$, or (2) $17 \beta$-estradiol $(\mathrm{N}=8)$ and prepared as described above. After a 1-hr, 15-min stabilization period, samples were collected at 5 -min intervals. Two baseline samples were collected, then $10 \mu \mathrm{M}$ $\mathrm{d}$-amphetamine sulfate (AMPH) was infused for $2.5 \mathrm{~min}$ and samples were collected for an additional $30 \mathrm{~min}$. 
Effects of estrogens on basal and KCl-stimulated DA release: dose response

Striatal tissue from OVX female rats was collected and placed into superfusion chambers containing medium without steroids. After a 1-hr, 15-min stabilization period, samples were collected at 10 -min intervals. Two baseline samples were collected, then medium containing either $17 \beta$-estradiol dissolved in $0.0015 \%$ ethanol $(10 \mathrm{pg} / \mathrm{ml}, \mathrm{N}=6 ; 100 \mathrm{pg} / \mathrm{ml}, \mathrm{N}=6 ; 1,000 \mathrm{pg} / \mathrm{ml}, \mathrm{N}=7)$, 17alpha-estradiol $(100 \mathrm{pg} / \mathrm{ml}, \mathrm{N}=6$ or $1,000 \mathrm{pg} / \mathrm{ml}$, $\mathrm{N}=6)$ or vehicle $(\mathrm{N}=6)$ was infused for the remainder of the superfusion. (Vehicle rather than cholesterol was used as a control in this and subsequent experiments since the membrane effects of cholesterol are quite different from those of the steroid hormones (Alfsen, 1983) and cholesterol may have specific effects on the $\mathrm{Na}+/ \mathrm{K}+$ ATPase (Deliconstantinos et al., 1989)). Thirty min after the onset of hormone or vehicle infusion, tissue was stimulated by the infusion of $60 \mathrm{mM} \mathrm{KCl}$ for $2.5 \mathrm{~min}$ and samples were collected at $10-\mathrm{min}$ intervals for an additional $20 \mathrm{~min}$.

\section{Influence of pulsatile infusion of estradiol on striatal DA release}

Striatal tissue from OVX females or CAST male rats was collected on ice in medium without steroids. After a 1-hr, 15-min stabilization period, samples were collected at 10-min intervals. Two baseline samples were collected, then medium containing 17ß-estradiol (90 $\mathrm{pg} / \mathrm{ml}$ dissolved in $0.0015 \%$ ethanol) or vehicle was infused for $10 \mathrm{~min}$ (pulse \#1). Tissue was superfused with steroid-free medium for $20 \mathrm{~min}$, then a second 10 -min pulse of $17 \beta$-estradiol (or vehicle) was delivered. Steroid-free medium was infused for an additional 20 min followed by pulse \#3 of $17 \beta$-estradiol or vehicle. Samples were collected for an additional $50 \mathrm{~min}$ after delivery of the last pulse. At the beginning of the last 10 -min interval, $60 \mathrm{mM} \mathrm{KCl}$ was infused for $2.5 \mathrm{~min}$. To control for the total amount of hormone that striatal tissue was exposed to during the superfusion, a second set of chambers were run in parallel with the superfusion chambers receiving 3 pulses of estradiol. In these chambers, after the two baseline samples were collected, tissue was continuously exposed to medium containing $30 \mathrm{pg} / \mathrm{ml} 17 \beta$-estradiol or vehicle for $90 \mathrm{~min}$, two additional samples were collected after hormone administration was terminated, and then $60 \mathrm{mM} \mathrm{KCl}$ was infused during the first $2.5 \mathrm{~min}$ of the last $10-\mathrm{min}$ sample.

\section{Statistical analysis}

The analysis was conducted using Statview $512+$ for the Macintosh computer. Comparisons between groups were made using analysis of variance. Subsequent pairwise comparisons were made with Fisher's Least Significant Difference Probability Test.

\section{RESULTS \\ Effects of estrogens on AMPH-stimulated DA release}

AMPH-stimulated DA release from striatal tissue of OVX female rats was increased after exposure in vitro to 17ß-estradiol (main effect vs. cholesterol: $F(1,20)=$ $6.80, p=0.017$; Fig. 1). As illustrated in Figure 1, in the presence of $17 \beta$-estradiol, AMPH stimulated greater striatal DA release at all time points compared with the response of tissue exposed to cholesterol. The nonsteroidal estrogen analogue DES also potentiated striatal DA release (significant group $\times$ time interaction, DES vs. cholesterol: $F(3,36)=2.86, p<0.05$; Table I). Treatment with 17alpha-estradiol tended to potentiated striatal DA release induced by AMPH, although for 17alpha-estradiol this effect did not reach statistical significance $(p=0.062$; Table I). With striatal tissue from intact male rats, AMPH-stimulated DA release was not influenced by prior exposure to $17 \beta$-estradiol in vitro (Table I).

\section{Effects of estrogens on basal and KCl-stimulated DA release}

$\mathrm{KCl}$-induced greater DA release after striatal tissue was exposed for $30 \mathrm{~min}$ to $100 \mathrm{pg} / \mathrm{ml} 17 \beta$-estradiol ( $p<0.05$; Fig. 2). In contrast, there was decreased DA release after exposure to the higher concentration of $1,000 \mathrm{pg} / \mathrm{ml} 17 \beta$-estradiol $(\mathrm{F}(2,16)=10.971, \mathrm{p}<0.001$; pairwise comparisons: $100 \mathrm{pg} / \mathrm{ml}>$ vehicle or $1,000 \mathrm{pg} /$ $\mathrm{ml}, \mathrm{p}<0.05$; vehicle $>1000 \mathrm{pg} / \mathrm{ml}, \mathrm{p}<0.05$; Fig. 2). Neither concentration of 17alpha-estradiol had a significant effect on KCl-induced DA release compared with vehicle $(\mathrm{F}(2,15)=0.145, \mathrm{p}=0.866$; Fig. 2). Basal DA release was not influenced by the continuous infusion of 17ß-estradiol or 17alpha-estradiol for $30 \mathrm{~min}$ (Fig. 2).

\section{Influence of pulsatile infusion of estradiol on striatal DA release}

The pulsatile infusion of $17 \beta$-estradiol stimulated DA release from striatal tissue of OVX female rats ( $<<0.05$; Fig. 3). Due to the high variability in basal striatal DA release obtained in tissue from CAST males, DA release following the infusion of $17 \beta$-estradiol is expressed as a percent of the mean baseline release rate in Figure 3. As illustrated in Figure 3, 20 min after the first $17 \beta$-estradiol pulse, there was an increase in striatal DA release from tissue of OVX females. This increased release was sustained until $20 \mathrm{~min}$ after the 3rd $17 \beta$-estradiol pulse. There appears to be a tendency for the tissue from CAST males to show an increase after $17 \beta$-estradiol pulses also, but the response was not sustained and did not approach statistical significance (Table II). The values for release rates in $\mathrm{pg} / \mathrm{mg} / \mathrm{min}$ are presented in Table II. As can be seen, the 17 $\beta$-estradiolinduced increase in striatal DA release from OVX tissue was significantly greater than release from OVX tissue not exposed to $17 \beta$-estradiol or release from tissue of CAST males with or without pulsatile $17 \beta$-estradiol treatment $(p<0.05)$. There was no effect of pulsatile estradiol pretreatment on $\mathrm{KCl}$-induced striatal DA release (Table II).

In contrast to the dramatic effect of pulsatile $17 \beta$ estradiol on striatal DA release, the continuous infusion of same total amount of $17 \beta$-estradiol had no effect on basal striatal DA release. However, with striatal tissue from OVX rats, the KCl-induced release of DA was significantly decreased after the continuous infusion of $30 \mathrm{pg} / \mathrm{ml} 17 \beta$-estradiol for 90 min compared with the response of tissue exposed to vehicle $(\mathrm{p}<0.02$; Table II). The response to $\mathrm{KCl}$ of striatal tissue from CAST males was not attenuated or potentiated by continuous estradiol (Table II). 


\section{A. CHOLESTEROL}

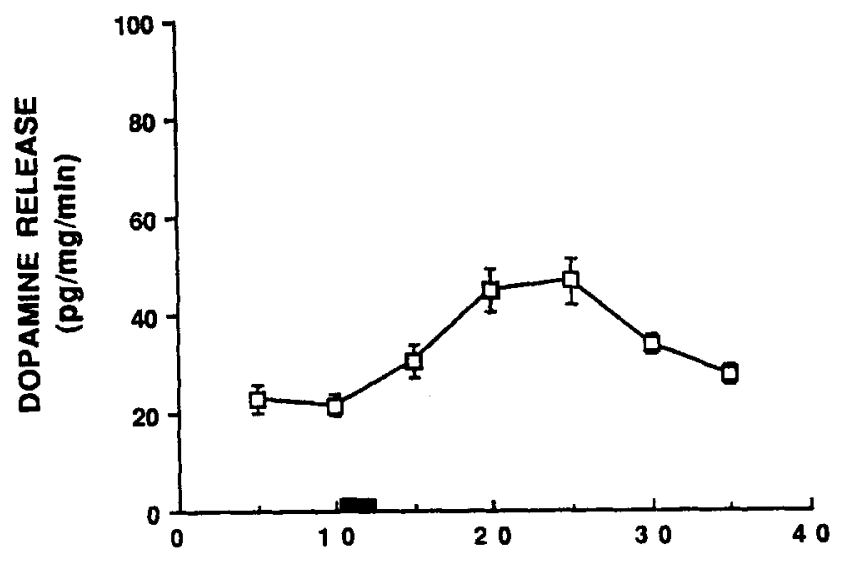

B. 17B-ESTRADIOL

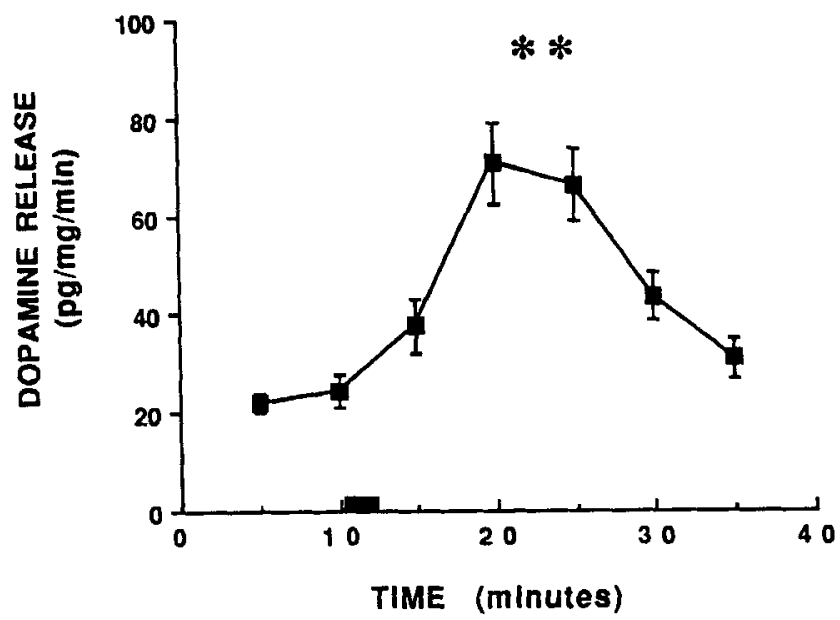

Fig. 1. The effect of $17 \beta$-estradiol on AMPH-stimulated DA release from striatal tissue of OVX rats. Striatal tissue was superfused in the presence of: (A) $60 \mathrm{pg} / \mathrm{ml}$ cholesterol $(\mathrm{N}=8)$ or (B) $60 \mathrm{pg} / \mathrm{ml} 17 \beta$ estradiol $(N=14)$. After a 75 -min stabilization period, samples were collected at 5-min intervals. Time " 0 " is the beginning of sample collection. After 2 baseline samples were collected, $10 \mu \mathrm{M}$ AMPH was infused for $2.5 \mathrm{~min}$ (indicated by the solid bars). **There was significantly greater AMPH-stimulated DA release from striatal tissue exposed to 17B-estradiol (B) than from striatal tissue exposed to cholesterol (A) during all 5 intervals after AMPH infusion $(F(1,20)=6.80$, $p=0.017$ ).

\section{DISCUSSION}

These experiments demonstrate for the first time that estrogen can act directly on striatal tissue fragments in vitro to influence the release of endogenous DA. A physiological concentration of $17 \beta$-estradiol stimulated DA release when applied in a pulsatile regimen to striatal tissue from OVX rats in superfusion. Continuous infusion of $17 \beta$-estradiol increased striatal DA release induced by AMPH and either increased or inhibited the response to $\mathrm{KCl}$, depending on the dose and duration of $17 \beta$-estradiol infusion. These effects of $17 \beta-$ estradiol on DA release from striatal tissue were sexually dimorphic.

How does estradiol modulate the stimulated release of striatal DA? Autoradiographic studies to localize cells that concentrate estradiol have indicated that the striatum contains very few, if any, genome-activating estrogen receptors (Pfaff and Keiner, 1973). There is, however, indirect evidence for genomic receptors for estradiol in the striatum. Exposure of primary cultures of embryonic mouse striatum to $17 \beta$-estradiol $\left(10^{-9} \mathrm{M}\right)$ for 4-6 hr induces an increase in striatal D1-DA-induced activation of adenylate cyclase (Maus et al., 1989). Shorter times of exposure to $17 \beta$-estradiol or treatment of broken cells with estradiol was ineffective in this regard. The timing of this effect and requirement of intact cells suggests that these effects of $17 \beta$-estradiol may be mediated by a genomic mechanism. The results of this experiment are not conclusive, however, since various cell types were present in these cultures. It is possible that $17 \beta$-estradiol had a primary effect (mediated by a nongenomic mechanism) on one population of cells, and that these neurons in turn induced changes in striatal DA receptors by releasing some unknown agent that induced the change in receptor activity. Such a mechanism could explain both the time delay in the effect of $17 \beta$-estradiol (the response of the second cell could require protein synthesis), as well as the need to have intact cells to observe the response. Therefore, evidence for genomic estrogen receptors in striatum remains inconclusive. In the absence of strong evidence for genome-activating estrogen receptors in striatum, alternative mechanisms that may mediate the rapid effects of estradiol in striatum reported here are discussed.

A nongenomic effect of steroid hormones could potentially be mediated by either binding to specific extracellular membrane receptors or by incorporation into neuronal membranes. The idea that steroid hormones may act in the brain via a nongenomic mechanism is not a

TABLE I. Amphetamine-stimulated striatal dopamine release $(\mathrm{pg} / \mathrm{mg} / \mathrm{min})$ : effects of hormon administration

\begin{tabular}{|c|c|c|c|c|}
\hline Group & Treatment & $(\mathrm{N})$ & Basal DA Release & $\begin{array}{c}\text { AMPH-Stimulated } \\
\text { DA Release }\end{array}$ \\
\hline $\begin{array}{l}\text { OVX } \\
\text { OVX } \\
\text { OVX } \\
\text { OVX } \\
\end{array}$ & $\begin{array}{l}\text { Cholesterol } \\
17 \beta \text {-estradiol } \\
\text { 17alpha-estradiol } \\
\text { DES }\end{array}$ & $\begin{array}{l}(8) \\
(14) \\
(12) \\
(6) \\
\end{array}$ & $\begin{array}{l}24.5 \pm 2.8^{1} \\
23.4 \pm 2.1 \\
15.4 \pm 1.9 \\
19.2 \pm 4.6 \\
\end{array}$ & $\begin{array}{l}40.8 \pm 2.9^{2} \\
58.2 \pm 5.0^{*} \\
56.9 \pm 7.6 \\
61.8 \pm 5.1^{*}\end{array}$ \\
\hline $\begin{array}{l}\text { Male } \\
\text { Male }\end{array}$ & $\begin{array}{l}\text { Cholesterol } \\
17 \beta \text {-estradiol }\end{array}$ & $\begin{array}{l}(4) \\
(8) \\
\end{array}$ & $\begin{array}{l}30.8 \pm 8.1 \\
17.6 \pm 3.1\end{array}$ & $\begin{array}{l}62.6 \pm 6.6 \\
60.9 \pm 5.6\end{array}$ \\
\hline
\end{tabular}

${ }^{l}$ Mean \pm SEM of 2 baseline samples (collected at 5 -min intervals).

2 Mean \pm SEM of 3 samples immediately following administration of $10 \mu \mathrm{M}$ AMPH for $2.5 \mathrm{~min}$

*Significantly different from OVX-cholesterol group $(\mathrm{p}<0.05)$. 


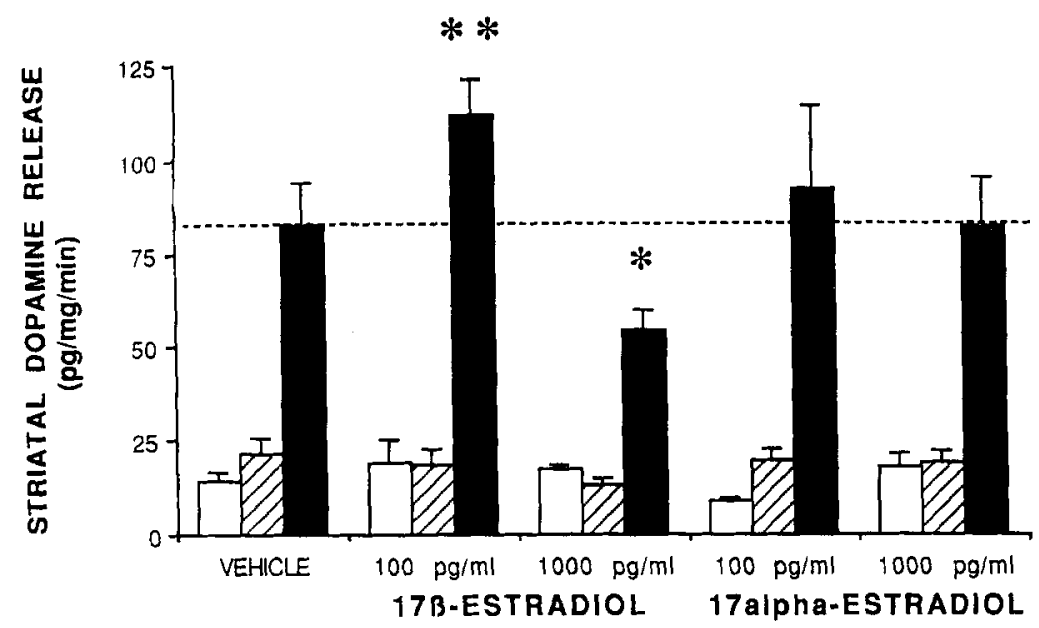

Fig. 2. Effects of 17ß-estradiol or 17alpha-estradiol on basal and $\mathrm{KCl}$-stimulated striatal DA release from striatal tissue of OVX females. Samples were collected at 10-min intervals; the bars represent the mean+SEM for 2 baseline samples (open bars); 3 samples collected in the presence of steroid or vehicle (hatched bars), or KCl-induced DA release (solid bars). Treatment groups (shown above left to right): (1) Vehicle $(\mathrm{N}=6) ;(2) 100 \mathrm{pg} / \mathrm{ml} 17 \beta$-estradiol. $(\mathrm{N}=6) ;(3) 1,000 \mathrm{pg} /$ ml 17ß-estradiol $(N=7) ;(4) 100 \mathrm{pg} / \mathrm{ml} 17$ alpha-estradiol $(\mathrm{N}=6)$; and
(5) $1,000 \mathrm{pg} / \mathrm{ml} 17$ alpha-estradiol $(\mathrm{N}=6)$. The dotted line indicates the average response of the vehicle group for reference purposes. $* * \mathrm{KCl}-$ stimulated DA release was significantly greater from striatal tissue treated with $100 \mathrm{pg} / \mathrm{ml} 17 \beta$-estradiol than from tissue treated with either vehicle or $1,000 \mathrm{pg} / \mathrm{ml} 17 \beta$-estradiol $(\mathrm{p}<0.05)$. ${ }^{*} \mathrm{KCl}$-stimulated DA release was significantly less from striatal tissue treated with $1,000 \mathrm{pg} / \mathrm{ml} 17 \beta$-estradiol than from tissue treated with vehicle $(\mathrm{p}<0.05)$.

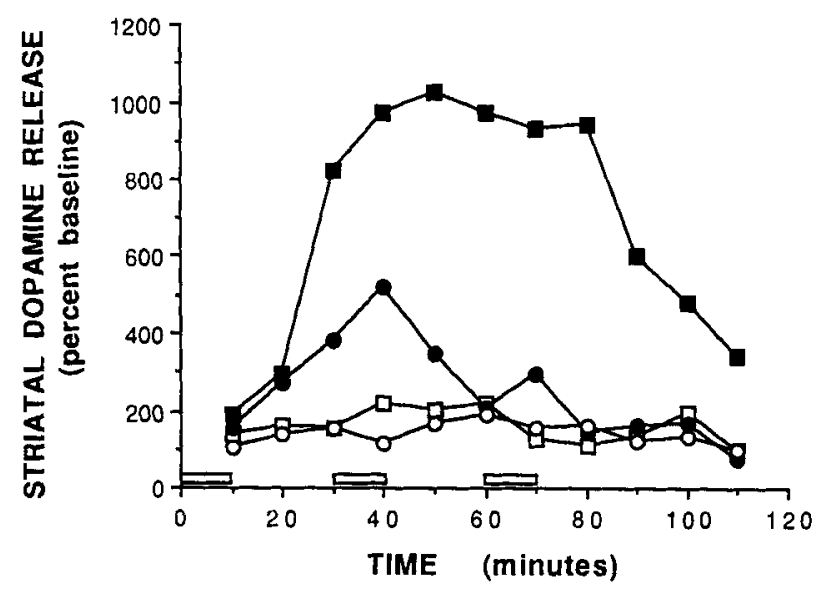

Fig. 3. Effects of pulsatile $17 \beta$-estradiol on DA release from striatal tissue of OVX female and CAST male rats. Striatal DA release after infusion of 173-estradiol or vehicle is expressed as a percent of the baseline release rate for presentation due to variability in baseline rates obtained from tissue of CAST males. Closed squares: OVX 17ß-estradiol $(\mathrm{N}=13)$; open squares: OVX vehicle $(\mathrm{N}=8)$; Closed circles: CAST $17 \beta$-estradiol ( $N=15$ ), open circles: CAST vehicle $(N=10)$. The open bars at the bottom of the figure indicate the periods of time during which $17 \beta$-estradiol $(90 \mathrm{pg} / \mathrm{ml})$ or vehicle were infused. Statistics were conducted on both percent baseline values as well as on the raw release rate values ( $\mathrm{pg} / \mathrm{mg} / \mathrm{min}$ ). The results of the statistical analyses were consistent for both measures, results of analyses on actual release rate values are presented here. Pulsatile 17ß-estradiol stimulated striatal DA release from tissue obtained from OVX females but not CAST males. A two-way ANOVA with repeated measures across all four groups indicated a main effect of hormone treatment $(\mathrm{F}(3,40)=2.8, \mathrm{p}=0.05)$ with no interaction. Subsequent analysis of the time course of the effect indicated that the OVX group receiving pulsatile estradiol was significantly different from the OVX vehicle group at all time points (main effect: $F(1,19)=7.512, p<0.013$ ). See Table II and text for additional details. new idea; membrane receptors for steroid hormones have been hypothesized based on neurochemical and electrophysiological evidence (for review see McEwen et al., 1979). However, biochemical evidence of membrane receptors for steroid hormones has not been conclusive. It is well known that steroids are lipophillic and therefore will incorporate into the lipid membranes of neurons and other cells. Because of this, the concept of a membrane effect of steroid hormones is frequently thought of as "nonspecific." This is not necessarily the case. Since steroids are rigid in structure, their incorporation into cell membranes can have specific effects. According to a review by Alfsen (1983) steroids can: (1) modify the structure and dynamics of the lipid membrane; (2) modify the structure and dynamics of the surrounding aqueous medium, and/or (3) modify the conformation of the surrounding membrane proteins thereby inducing their transformation into an active or inactive form. These membrane effects can be both steroid specific and stereospecific, depending upon the environment in which the steroid is found (e.g., presence or absence of steroid-binding proteins, specific composition of lipid bilayer membrane, etc.). Therefore, the finding in this report, that the effects of $17 \beta$-estradiol are mimicked by DES and that 17alpha-estradiol is not as effective in this regard, are consistent with either a genome-activating estrogen receptor or a membrane mediated response.

Receptor mediated responses usually increase with increasing receptor occupation until the receptor is saturated (McGonigle and Molinoff, 1989). The finding reported here that physiological concentrations of estradiol increase, whereas higher doses or prolonged exposure to estradiol decrease, $\mathrm{KCl}$-induced striatal DA 
TARLE II. Striatal dopamine release $(\mathrm{pg} / \mathrm{mg} / \mathrm{min})$ : effects of pulsatile vs. continuous estradiol an'ministration

\begin{tabular}{|c|c|c|c|c|c|}
\hline Group & Treatment & $(\mathrm{N})$ & Basal Release & $\begin{array}{c}\text { Increase After } \\
\text { Hormone or } \\
\text { Vehicle Infusion }\end{array}$ & $\begin{array}{c}\mathrm{KCl} \\
\text { Stimulation }\end{array}$ \\
\hline \multicolumn{6}{|c|}{ Pulsatile Administration ( $90 \mathrm{pg} / \mathrm{ml}$-three 10 -min pulses over $90 \mathrm{~min}$ ) } \\
\hline ovX & vehicle & (8) & $5.2 \pm 1.0^{2}$ & $3.3 \pm 2.1^{2}$ & $81.3 \pm 9.6^{3}$ \\
\hline ovX & $17 \beta$-estradiol & (13) & $6.0 \pm 1.2$ & $13.6 \pm 2.7^{* *}$ & $69.0 \pm 10.5$ \\
\hline CAST & vehicle & (10) & $9.4 \pm 5.9$ & $4.4 \pm 2.1$ & $72.1 \pm 9.9$ \\
\hline CAST & $17 \beta$-estradiol & (15) & $9.5 \pm 1.6$ & $4.8 \pm 3.1$ & $81.0 \pm 14.0$ \\
\hline \multicolumn{6}{|c|}{ Continuous Administration $(30 \mathrm{pg} / \mathrm{ml}$ for $90 \mathrm{~min})$} \\
\hline ovX & vehicle & (9) & $7.0 \pm 2.3^{1}$ & $-0.9 \pm 2.5$ & $106.6 \pm 14.2^{3}$ \\
\hline OVX & $17 \beta$-estradiol & (9) & $7.2 \pm 1.8$ & $-2.8 \pm 1.3$ & $53.5 \pm 12.1^{*}$ \\
\hline CAST & $\begin{array}{l}\text { vehicle } \\
\text { nats }\end{array}$ & (7) & $6.0 \pm 1.2$ & $3.7 \pm 2.2$ & $95.7 \pm 19.4$ \\
\hline CAST & $17 \beta$-estradiol & (8) & $8.3 \pm 2.4$ & $1.8 \pm 3.6$ & $84.7 \pm 18.4$ \\
\hline
\end{tabular}

Mean \pm SEM of 2 baseline samples (collected at 10-min intervals).

${ }^{2}$ Mean \pm SEM of average increase (average of 9 samples during hormone or vehicle administration minus baseline)

${ }^{3}$ Mean \pm SEM of 1 sample immediately following administration of $60 \mathrm{mM} \mathrm{KCl}$ for $2.5 \mathrm{~min}$.

*Significantly different from OVX-vehicle (continuous administration) group ( $\mathrm{a}<0.02$ ).

** Increase in DA release significantly greater than pulsatile administration of vehicle to $\mathrm{OVX}$ and both pulsatile administration groups $\mathrm{CAST}(\mathrm{F}(3,42=2.95, \mathrm{p}<0.042$; pairwise comparisons, $p<0.05$.

release is not consistent with a genome-activating estrogen receptor mediated response. There is, however, one well-documented exception to the rule that the response to activation of receptors follows a saturable dose-response curve. The LHRH receptor system exhibits a bell-shaped dose-response curve and is sensitive to pulsatile stimuli (Conn, 1986). The finding that the pulsatile delivery of $17 \beta$-estradiol to striatal tissue of OVX female (but not male) rats stimulates DA release in addition to the bell-shaped dose-response curve suggests that there may be specific membrane receptors for $17 \beta$-estradiol. The mechanism thought to mediate this dose response profile for the LHRH receptor may provide some insight into how estradiol acts in the striatum. Activation of the LHRH receptor by LHRH induces the microaggregation of receptor subunits within the membrane and is thought to open $\mathrm{Ca}^{++}$channels (for reviews see Blum, 1985; Conn, 1986). The presence of high concentrations of LHRH produces a decreased response because LHRH is thought to simultaneously bind at two sites on the receptor to induce aggregation. In the presence of excess ligand, an individual LHRH molecule binds at only one site so aggregation does not occur. During the continuous presence of low concentrations of LHRH, binding to the receptor may occur at only one site, and receptor responsiveness is attenuated. A pulsatile stimulus restores receptor responsiveness by promoting microaggregation.

Receptor aggregation can be modulated by changes in membrane fluidity/rigidity (Blum, 1985). So, it is possible that the response to estradiol is mediated by a conformational change in membrane ion channels induced by the incorporation of estradiol into neuronal membranes. It is important to remember that the incorporation of estradiol into neuronal membranes is not necessarily a nonspecific effect (Alfsen, 1983). The presence of proteins within the membrane that are specifically activated or aggregated by estradiol is one possible mechanism that may mediate the responses reported here. Interestingly, prolonged exposure to estradiol attenuated the striatal DA response to $\mathrm{KCl}$, but potentiated the response to AMPH. This finding may reveal additional information about the mechanism mediating the effect of estradiol in the striatum, since these two agents induce DA release by different mechanisms. $\mathrm{KCl}$-induced DA release is $\mathrm{Ca}^{++}$-dependent in this system, whereas AMPH-induced I)A release is $\mathrm{Ca}^{++}$-independent (Becker et al., 1984). If prolonged exposure to estradiol results in changes in DA terminal ion channels, this could differentially affect the response to AMPH vs. KCl (Fischer and Cho, 1979). Further research will be needed to fully characterize the effects of estradiol on the presynaptic DA terminal.

There is prior evidence for the presence of nongenomic steroid hormone receptors in striatum. Physiological concentrations of progesterone also rapidly stimulate striatal DA release in vivo (Dluzen and Ramirez, 1984, 1989a) even when progesterone is conjugated to a large protein that prevents its entry into the cell (Dluzen and Ramirez, 1989b). If such a mechanism mediates the effects reported here, there may be a sexual dimorphism in the proteins found in striatal neuronal membranes since striatal DA release was modulated by estrogen only in tissue from female rats, whereas tissue from male rats was unresponsive. Striatal membranes from female rats may contain a receptor or other protein (e.g., ion channel, enzyme, etc.) that striatal membranes from male rats do not contain. Sex specific binding of steroid hormones has been found in microsomal membranes of rat liver (Blyth et al., 1971) so there is precedence from peripheral cell membranes for the presence of sex differences in cell membrane proteins.

If there are specific receptors or proteins sensitive to estradiol in striatum, what cells in striatum are they located upon? Maus et al. (1989) found that estradiol can modulate DA receptor activity in cultures of striatal neurons (that did not contain DA terminals). This suggests that estrogen may not act directly on DA terminals to produce the effects reported here. For example, the effect of estrogen may be mediated by either GABA or acetylcholine, since both have been shown to modulate striatal DA release in vitro and to synapse on presynaptic DA terminals (Glowinski et al., 1988). In addition, influences of estradiol on both cholinergic and GABAergic activity in striatum have been reported (Bandyopadhyay and Ghosh, 1988; Euvrard et al., 1979; Gordon 
et al., 1977; Hamon et al., 1983; Perez et al., 1986). It should be noted, however, that even if estrogen is active at nondopaminergic neurons in striatum, this does not necessarily rule out the possibility that there is also a direct effect on DA terminals. Localization of the site(s) of estrogen's action in striatum will be an important step toward determining the underlying mechanism(s) involved.

Nongenomic effects of steroid hormones in the brain are not limited to the striatum. For example, in the cerebellum local application of a physiological concentration of estradiol produces a very rapid $(40 \mathrm{~s})$ stereospecific increase in the responsiveness of Purkinje cells to glutamate (Smith et al., 1988). Progesterone can rapidly stimulate the release of LHRH from hypothalamic tissue in vitro, apparently in the absence of genome-activating progesterone receptors (Dluzen and Ramirez, 1989a,b) and local application of estrogen to hypothalamus or septal area rapidly alters neuronal firing rates (Kelly et al., 1977a,b; Poulain and Carette, 1981). In the hippocampus, furthermore, a rapid electrophysiological response to steroid hormones is sexually dimorphic (Teyler et al., 1980). Given the variety of sites in the brain that are responsive to gonadal steroids, their impact on neural function is probably more widespread than just those brain regions mentioned above and the behavioral effects of their actions must extend beyond gonadal hormone modulation of reproductive and allied behaviors. For example, performance on tests of verbal fluency and spatial abilities have been found to vary with the menstrual cycle in human females (Broverman et al., 1981; Hampson, 1988, 1989; Hampson and Kimura, 1988). These cognitive functions are thought to be mediated to a large extent by cortical activity. So, the cerebral cortex, and in particular those areas of the cortex involved in verbal and spatial functions, may also be targets for nongenomic effects of steroid hormones.

The sex difference in the effect of estradiol on striatal DA responsiveness to stimulation reported here may underlie some of the sex differences in neurochemical and behavioral indices of nigrostriatal DA activity that have been reported in the rat (e.g., Becker and Ramirez, 1980; Becker et al., 1982; Camp et al., 1986; Robinson et al., 1981, 1982). The finding that estrogen can directly modulate striatal DA activity in females may also be relevant to recent reports of menstrual cycle dependent variation in sensorimotor performance in humans (Hampson, 1988, 1989; Hampson and Kimura, 1988). Performance on sensorimotor tasks is improved during the late follicular phase and during the luteal phase of the menstrual cycle, compared to the menstrual phase of the cycle (Hampson, 1989; Hampson and Kimura, 1988). Improvement in sensorimotor performance was associated with an elevation in serum concentrations of estradiol during the late follicular phase and the elevation of both estrogen and progesterone during the luteal phase (Hampson, 1989). Whereas the execution of this sensorimotor task in humans no doubt involves participation by cortical (and other) brain areas in addition to the striatum, the parallel between these results and the effects of estrous cycle and intrastriatal estradiol on sensorimotor performance in female rats is quite striking. Female rats are the more accurate in performance of a sensorimotor task on estrus than on other days of the cycle, and the intrastriatal application of $17 \beta$-estra- diol produces rapid improvement in performance on this same task (Becker et al., 1987). Therefore, the direct modulation of striatal DA activity by estradiol is important both because of its nongenomic mechanism of action in the central nervous system and also because of its probable role in the modulation of sensorimotor function in species as diverse as rodents and humans.

\section{ACKNOWLEDGMENTS}

This research was supported by grants from the NIH (R01 NS25662 and KO4 NS01056).

\section{REFERENCES}

Alfsen, A. (1983) Biophysical aspects of the mechanism of action of steroid hormones. Prog. Biophys. Mol. Biol., 42: 79-93.

Bandyopadhyay, M., and Ghosh, A. K. (1988) Effect of prolonged use of contraceptive steroid hormones on acetylcholinesterase activity in some regions of brain in rat. Neuroendocrin. Lett., 10: 175-182.

Becker, J. B., and Beer, M. E. (1986) The influence of estrogen on nigrostriatal dopamine activity: behavioral and neurochemical evidence for both pre- and postsynaptic components. Behav Brain Res., 19(1): 27-33.

Becker, J. B., and Cha, J. (1989) Estrous cycle-dependent variation in amphetamine-induced behaviors and striatal dopamine release assessed with microdialysis. Behav. Brain Res. (in press).

Becker, J. B., and Ramirez, V. D. (1980) Sex differences in the amphetamine stimulated release of catecholamines from rat striatal tissue in vitro. Brain Res., 204(2): 361-372.

Becker, J. B., and Ramirez, V. D. (1981) Experimental studies on the development of sex differences in the release of dopamine from striatal tissue fragments in vitro. Neuroendocrinology $32(3)$ : 168-173.

Becker, J. B., Beer, M. E., and Robinson, T. E. (1984a) Striatal dopamine release stimulated by amphetamine or potassium: influence of ovarian hormones and the light-dark cycle. Brain Res., 311(1): $157-160$.

Becker, J. B., Robinson, T. E., and Lorenz, K. A. (1982) Sex differences and estrous cycle variations in amphetamine-elicited rotational behavior. Eur J Pharmacol., 80(1): 65-72.

Becker, J. B., Castaneda, E., Robinson, T. E., and Beer, M. E. (1984b) A simple in vitro technique to measure the release of endogenous dopamine and dihydroxyphenylacetic acid from striatal tissue using high performance liquid chromatography with electrochemical detection. J Neurosci Meth., 11: 19-28.

Becker, J. B., Snyder, P. J., Miller, M. M., Westgate, S. A., and Jenuwine, M. J. (1987) The influence of estrous cycle and intrastriatal estradiol on sensorimotor performance in the female rat. Pharmacol Biochem Behav, 27(1): 53-59.

Blum, J. J. (1985) The role of microaggregation in hormone-receptoreffector interactions. In: The Receptors, Vol. II. P. M. Conn, ed. Academic Press, New York, pp. 57-87.

Blyth, C. A., Freedman, R. B., and Rabin, B. R. (1971) Sex specific binding of steroid hormones to microsomal membranes of rat liver Nature., 230: 137-139.

Broverman, D. M., Vogel, W., Klaiber, E. L., Majcher, D., Shea, D., and Paul, V. (1981) Changes in cognitive task performance across the menstrual cycle. J. Comp. Physiol. Psychol,, 95:646-654.

Camp, D. M., Becker, J. B., and Robinson, T. E. (1986) Sex differences in the effects of gonadectomy on amphetamine-induced rotational behavior in rats. Behav Neural Biol., 46(3): 491-495.

Conn, P. M. (1986) The molecular basis of gonadotropin-releasing hormone action. Endocrin. Rev., 7:3-10.

Di Paolo, T., Falardeau, P., and Morissette, M. (1988) Striatal D-2 dopamine agonist binding sites fluctuate during the rat estrous cycle. Life Sci., 43(8):665-672.

Di Paolo T., Rouillard, C., and Bedard, P. (1985) 17ß-Estradiol at a physiological dose acutely increases dopamine turnover in rat brain. Eur J Pharmacol., 117(2): 197-203.

Dluzen, D. E., and Ramirez, V. D. (1984) Bimodal effect of progesterone on in vitro dopamine function of the rat corpus striatum. Neuroendocrinology, $39(2): 149-155$

Dluzen, D. E., and Ramirez, V. D. (1989a) Progesterone effects upon dopamine release from the corpus striatum of female rats. I. Evidence for interneuronal control. Brain Res., 476(2): 332-337.

Dluzen, D. E., and Ramirez, V. D. (1989b) Progesterone effects upon dopamine release from the corpus striatum of female rats. II. Evidence for a membrane site of action and the role of albumin. Brain Res., 476(2): 338-344.

Euvrard, C., Labrie, F., and Boissier, J. R. (1979) Effect of estrogen on 
changes in the activity of striatal cholinergic neurons induced by DA drugs. Brain Res., 169(1): 215-20.

Fischer, J. F., and Cho, A. K. (1979) Chemical release of dopamine from striatal homogenates: evidence for an exchange diffusion model. J. Pharmacol. Exp. Ther., 208: 203-209.

Glowinski, J., Cheramy, A., Romo, R., and Barbeito, L. (1988) Presynaptic regulation of dopaminergic transmission in the striatum. Cell. Molec. Neurobiol., 8: 7-17.

Gordon, J. H., Nance, D. M., Wallis, C. J., and Gorski, R. A. (1977) Effects of estrogen on dopamine turnover, glutamic acid decarboxylase activity and lordosis behavior in septal lesioned female rats. Brain Res Bull., 2(5): 341-346.

Hamon, M., Goetz, C., Euvrard, C., Pasqualini, C., Le Dafniet, M., Kerdelhue, B., Cesselin, F., and Peillon, F. (1983) Biochemical and functional alterations of central GABA receptors during chronic estradiol treatment. Brain Res., 279: 141-152.

Hampson, E. (1988) Variation in sex-related cognitive abilities across the menstrual cycle. Research Bulletin No. 669, London, Ontario. University of Western Ontario Department of Psychology.

Hampson, E. (1989) Estrogen-related fluctuations in human spatial and articulatory-motor performance. Research Bulletin No. 686, London, Ontario, University of Western Ontario Department of Psychology.

Hampson, E., and Kimura, D. (1988) Reciprocal effects of hormonal fluctuations on human motor and perceptual-spatial skills. Behavioral Neuroscience, 102:456-459.

Hruska, R. E. (1986) Elevation of striatal dopamine receptors by estrogen: dose and time studies. J Neurochem., 47(6): 1908-15.

Hruska, R. E., and Pitman, K. T. (1982) Distribution and localization of estrogen-sensitive dopamine receptors in the rat brain. J Neurochem., 39(5): 1418-23.

Hruska, R. E., and Silbergeld, E. K. (1980) Estrogen treatment enhances dopamine receptor sensitivity in the rat striatum. Eur $\mathrm{J}$ Pharmacol., 61(4): 397-400.

Hruska, R. E. Ludmer, L. M. Pitman, K. T., De Ryck, M. and Silbergeld, E. K. (1982) Effects of estrogen on striatal dopamine receptor function in male and female rats. Pharmacol Biochem Behav., 16(2): 285-291.

Joyce, J. N., and Van Hartesveldt, C. (1984a) Behaviors induced by intrastriatal dopamine vary independently across the estrous cycle. Pharmacol Biochem Behav., 20(4): 551-557.

Joyce, J. N., and Van Hartesveldt, C. (1984b) Estradiol application to one striatum produces postural deviation to systemic apomorphine. Pharmacol Biochem Behav., 20(4): 575-581.

Kelly, M. J., Moss, R. L., and Dudley, C. A. (1977a) The effects of microiontophorectically applied estrogen, cortisol, and acetylcholine on the medial preoptic-septal unit activity throughout the estrous cycle of the female rat. Exptl. Brain Res., 30:53-64.

Kelly, M. J., Moss, R. L., Dudley, C. A., and Fawcett, C. P. (1977b) The specificity of the response of preoptic-septal area neurons to estrogen: 17 alpha-estradiol versus $17 \beta$-estradiol and the response of extrahypothalamic neurons. Exptl. Brain Res., 30:43-52.

Levesque, D., and Di Paolo, T. (1988) Rapid conversion of high into low striatal D2-dopamine receptor agonist binding states after an acute physiological dose of 17 beta-estradiol. Neurosci Lett., 88(1): $113-118$.

Levesque, D., Gagnon, S., and Di Paolo, T. (1989) Striatal D1 dopamine receptor density fluctuates during the rat estrous cycle. Neurosci. Lett., 98: 345-350.

McEwen, B.S., Davis, P.G., Parsons, B., and Pfaff, D.W. (1979) The brain as a target for steroid hormone action. Ann. Rev. Neurosci., 2:65-112.

McGonigle, P., and Molinoff, P. B. (1989) Quantitative aspects of drug-receptor interaction. In: Basic Neurochemistry, 4th ed. G. Siegel, B. Agranoff, R.W. Albers, and Y'. Molinoff, eds., Raven Press, New York, pp. 183-201.

Maus, M., Bertrand, P., Drouva, S., Rasolonjanahary, R., Kordon, C. Glowinski, J., Premont, J., and Enjalbert, A. (1989) Differential modulation of D1 and D2 dopamine-sensitive adenylate cyclases by $17 \beta$-estradiol in cultures striatal neurons and anterior pituitary cells. J. Neurochem., 52: 410-418.

Perez, J., Zucchi, I., and Maggi, A. (1986) Sexual dimorphism in the response of the GABAergic system to estrogen administration. J. Neurochem., 47: 1798-1803.

Pfaff, D., and Keiner, M. (1973) Atlas of estradiol-concentrating cells in the central nervous system of the rat. Comp. Neur., 151:121-158.

Poulain, P., and Carette, B. (1981) Pressure ejection of drugs on single neurons in vivo: Technical considerations and application to the study of estradiol effects. Brain Res Bull., 7: 33-40.

Robinson, T. E., Camp, D. M., and Becker, J. B. (1981) Gonadectomy attenuates turning behavior produced by electrical stimulation of the nigrostriatal dopamine system in female but not male rats. Neurosci Lett., 23(2): 203-208.

Robinson, T. E., Camp, D. M., Jacknow, D. S., and Becker, J. B. (1982) Sex differences and estrous cycle dependent variation in rotational behavior elicited by electrical stimulation of the mesostriatal dopamine system. Behav Brain Res., 6(3): 273-287.

Smith, S. S., Waterhouse, B. D., and Woodward, D. J. (1988) Locally applied estrogens potentiate glutamate-evoked excitation of cerebellar purkinje cells. Brain Res., 475:272-282.

Teyler, T. J., Vardaris, R. M., Lewis, D. L., and Rawitch, A. B. (1980). Gonadal steroids: effects on excitability of hippocampal pyramidal cells. Science., 209: 1017-19. 